\title{
Dynamic Capabilities and Digital Marketing in Small and Medium-Sized Enterprises (SMEs) in Indonesia: a Systematic Analysis of Literature and Conceptual Model
}

\author{
Anton Wardaya, Sasmoko ,Idris Gautama So, Agustinus Bandur
}

\begin{abstract}
Small and Medium sized enterprises (SMEs) have proven to be the backbone of Indonesia's economy. It gives contribution to $99.9 \%$ of national economic, absor $97 \%$ employee and contributes $60.34 \%$ to Indonesia GDP. Indonesia is known to be one of the most social media users. There is lack of studies to understand the role of dynamic capabilities and digital marketing on influencing the performance of SME's in Indonesia. This study aims to develop a conceptual model linking dynamic capabilities, digital marketing capabilities and SME performance. Systematic literature review (SLR) method is used in this study. After getting result of SLR, than the authors develope the concept. More than 2000 publication published from 2011 to 2018 were screened with dynamic capabilities, digital marketing and SMEs' performance as keywords. Finally, 20 journals were included for this review. Based on the review there were three possible relationships in the conceptual model which are (1) there is a positive relationship between dynamic capabilities and firm performance; (2) there is a positive relationship between dynamic capabilities and digital marketing capabilities and (3) there is a positive relationship between digital marketing capabilities and firm performance. It concludes with the need for further study to find empirical validation of the three relationships. Contribution of this study is giving the conceptual framework that both dynamic capabilities and digital marketing capabilities might have important roles to SMEs' performance in Indonesia.
\end{abstract}

Index Terms: digital marketing capabilities, dynamic capabilities, SMEs' performance

\section{INTRODUCTION}

Indonesia is one of the countries with the largest number of media social users in the world. Social Media is a network

\section{Revised Manuscript Received on October 15, 2019}

Anton Wardaya, Doctoral Student at Doctor of Research Management program in Entrepreneurship and Innovation stream, at Bina Nusantara University, Indonesia. Lecturer in Entrepreneurship, Bina Nusantara University

Sasmoko, Professor in Bina Nusantara University, Indonesia

Head of Research interest in Educational Technology, Bina Nusantara University

Idris Gautama So, Doctor of Philosophy (Ph.D) in marketing from Universiti Sains Malaysia. Former vice rector Global Employability and Entrepreneurship, former dean, school of business management in Bina Nusantara University. Lecturer in Entrepreneurship and Innovation Stream, at Bina Nusantara University

Agustinus Bandur, Doctor of Philosophy (Ph.D) in Leadership and Management Education from The University of Newcastle, Australia. Senior Lecturer \& Strategic Research and Partnership Team Leader media used in this digital era (1). Even according to previous research, We are Social (2019), of the total population of 268.2 million Indonesians, it was found that 150 million of them had used social media with a penetration rate of around $56 \%$. This means that there is an increase of 20 million social media users in Indonesia, compared to 2018. The use of internet services that are often accessed by Indonesian people is chat with $89.35 \%$ and social media reaching $87.13 \%$. Furthermore, according to We are Social (2019), there are 4 social media that are often used by Indonesians, namely Facebook (86.67\%), Instagram (41.3\%), Twitter (4.28\%) and Snapchat $(2.53 \%)$.

According to a survey conducted by the IDN Research Institute (2019), there are as many as $70.4 \%$ of millennials who access digital media to find out the latest news. The main reason for choosing digital media is the ease of access and speed of access. In addition, the millennial generation dominates and is very active in the use of social media. Some of the most commonly used social media are Facebook (62.6\%), Instagram (38\%) and Twitter (1.2\%). Within a day, they often update status between 2-5 times as much as $79.5 \%$ and $6-8$ times as much as $52.5 \%$.

The variety of social media accounts owned shows millennial familiarity with the use of social media. They are easy to share experiences and activities on social media. A survey conducted by the IDN Research Institute (2019), showed that there were 4 goals most often carried out by millennials in accessing the internet, namely chat / messaging $(81.3 \%)$, browsing $(77.4 \%)$, social networking $(74.4 \%)$ and video streaming $(40.7 \%)$. This proves that the internet has many functions because various activities are carried out through the internet. Millennials are generations that are connected to each other. Through social media, friendship networks and access to information are increasingly widespread. Networks that are built are not only based on the local environment such as a place to live or work, but can reach more widely. Millennials have the character to maintain solidarity in Indonesia. The presence of the internet has brought many changes. Before there was the internet, buyers needed considerable effort to find out an item. People must come to various stores to compare products with each other. But with the help of the internet, finding information about a

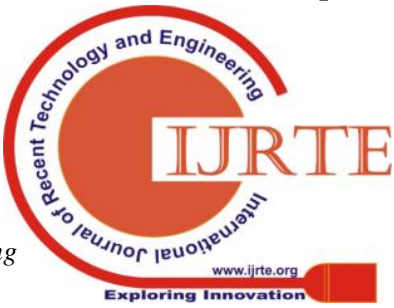




\section{Dynamic Capabilities and Digital Marketing in Small and Medium-Sized Enterprises (SMEs) in Indonesia: A Systematic Analysis of Literature and Conceptual Model}

product is getting easier.

A total of $59.7 \%$ millennials are looking for a price comparison for a product through the internet before purchasing the product (IDN Research Institute, 2019). Millennial activity is inseparable from digital support. From starting culinary to tourism, it's easier to find favorite eating place references through online sites. Even millennials shop online. This shows that the millennial generation is ready to bring Indonesia to face changes due to the industrial revolution 4.0 and to make this country go massive digital revolution

SMEs contribute $99.9 \%$ in Indonesia's economy (Tambunan, 2007) and absorb employee reaches $97 \%$. Beside that SMEs contribute to GDP reach to $60.34 \%$ (5). Based on the Annual Report of European SMEs (2016/2017), the number of MSMEs in developed countries was also assessed by MSMEs, amounting to $99.8 \%$ while micro businesses were only $93 \%$. While the structure of MSMEs in Indonesia is very important by micro-enterprises, which is $98.7 \%$ and unchanged from 10 years ago. This shows that micro-businesses in Indonesia never scaling up to small or medium-sized businesses.

Indonesia has around 59,687 million MSMEs where the number of micro businesses reaches $98.68 \%$, small businesses reach $1.2 \%$, medium enterprises reach $0.11 \%$ and large businesses only $0.01 \%$ (Ministry of Cooperatives and SMEs, 2017). The indicator of the success of an SME is calculated based on profits received, not based on turnover. Based on the results of a World Bank (2017), there are four problems faced by SMEs in developing countries. First is the difficulty of access to finance. Both difficulties in access and opportunities to open a business. Third is the capacity of human resources and institutional SMEs. The last is regulation and biroraksi While the factors that greatly influence the success of SMEs in Indonesia are access to finance, marketing, technology and quality human resources (9).

The internet is seen as a way to solve problems in Indonesia. So from the data that has been presented, Indonesia has great potential in technology and innovation. Digital technology, innovation and digital transformation have changed the patterns of business, products and patterns of relationships with each other. Large mobile phone, internet and active social media users in Indonesia, will increasingly open opportunities and facilitate SMEs in promoting and developing businesses through digital media. Marketing using the internet is what is known as digital marketing. People no longer need to market conventionally their goods / services. They can market their items through social media such as Facebook, Instagram, Whatsapp, Line and others. Digital marketing has a tremendous impact. According to data obtained from the APJII (2017), it shows that internet usage in the economic sector is $32.19 \%$ online and $16.83 \%$ for online sales.

\section{METHODOLOGY}

For selecting journals, the authors used PRISMA systematic review that related with this research (11).
Authors search keywords "Dynamic Capabilities", "Digital Marketing Capabilities" and "Firm Performance" in Science Direct. The authors found 2524 journal publications. The authors then limited the year of journal's publication from 2011 until 2018 and found 1099 journal publications.

The authors then limited the source to Social Science journals, namely Journal of Business Research, Technovation, Procedia -Social and Behavior. After reviewing duplication and relevant, 71 journals published from 2011 to 2018 were found. After screening based type of relevant industry and methodology, finally 20 journals were included in the systematic review.

\section{RESULTS}

After review thirty four journals, the authors found that there are three main topic. The first category discusses the relationship between Dynamic Capabilities and Firm Performance. The second is the relationship between Dynamic Capabilities and Digital Marketing Capabilities. The last one is about the relationship between Digital Marketing Capabilities and Firm Performance.

\section{A. Dynamic Capabilities and Firm Performance}

Dynamic capability affects the performance of SMEs (Lin and $\mathrm{Wu}, 2014)$. Dynamic capability is built and redeveloped owned resources. SMEs that are closely related to customers, suppliers and partners. Dynamic capability has a positive influence on the performance of SMEs with a changing environment.

Dynamic capability increases the efficiency, speed and efficiency of SME responses to environmental turbulence, which in turn improves SME performance. Freeing SMEs can take advantage and profit to increase profits while adjusting operations to save costs associated with products and services. This dynamic capability enables SMEs to survive and grow by being able to adapt to their external environment (14).

The higher the dynamic capability of an SME to change and adapt to the environment, the higher the response of SMEs in terms of revenue generated (15). According to another study, Ringov (2017), dynamic capability and environmental dynamics will be moderated by the difficulties of the company's asset base. Previously based on previous research, Jantunen, Tarkiainen, Chari, \& Oghazi (2018), companies that have the capacity to identify opportunities and coordinate their resources can renew their business models and support business changes using technology and market changes.

\section{B. Dynamic Capabilities and Digital Marketing Capabilities}

Dynamic capabilities read opportunities and threats by exploring markets and technology. The possibility of investing in relevant technology to reach market demand. (14). Dynamic capability identifies new market opportunities and uses them. 
Companies that are most able to deal with market changes and technology are very fast, develop capability to feel changes and take advantage of opportunities faster than their competitors. They are more resilient, make timely decisions and are able to adapt to rapid market and technological changes (18).

In a growing market, dynamic capabilities enable companies to identify important market signals, evaluate new processes or services or products and respond to market changes. Information technology creates an environment where competitive advantage can be enhanced through process excellence, service excellence and intimacy with customers. Digital marketing capabilities affect long-term customer relations (19).

Digital marketing makes it possible for companies to provide accurate insights about customers, markets, competitors, environmental trends, distributors, alliance partners, communities that are done online (20). SMEs in Indonesia already have a Facebook Fan Page and are interested in the concept of trading through Facebook. Currently what has been commonly used by SMEs in Indonesia is SMS Text (21).

\section{Digital Marketing Capabilities and Firm Performance}

Network resources are mediation of entrepreneurial orientation towards company performance (22). Marketing capability has a positive influence on the performance of SMEs(23,24), namely SME finance (25), SME goals and competitors (26). Marketing capability is the main determinant of competitive advantage of SMEs. Marketing capabilities are adaptive and allow SMEs to adapt their strategies to rapidly changing markets (27).

Competitive strategies mediate marketing capabilities with SME performance. This competitive strategy makes costs lower and the market reach broader (28). Digital-based marketing makes SMEs more effective and can reduce costs in various ways (27). Entrepreneurial orientation by mediating marketing capabilities increases company performance higher than the direct path from entrepreneurial orientation to company performance (29).

Marketing orientation and marketing strategies moderate the relationship between marketing capabilities and SME performance (26). SME marketing capabilities improve the superiority and differentiation of new products with the help of technology (30). Social media is a successful tool for building brands and attracting new customers and building relationships with customers. The use of social media affects sales and customer commitment to the brand (31). According to previous research (21), SMEs in Indonesia argue that Facebook can increase buying interest from prospective buyers, when prospective buyers receive recommendations from friends on social networks.

\section{DISCUSSION}

The authors propose a relationship between dynamic capabilities, digital marketing capabilities, and firm performance.
P1: Dynamic Capabilities has a positive direct influence on firm performance

P2: Dynamic Capabilities will positively influence digital marketing capabilities

P3: Digital marketing capabilities will positively influence firm performance

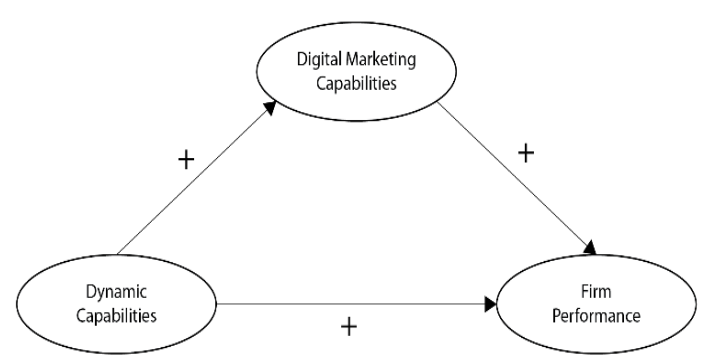

Fig 1.Propose Model Relationship of Dynamic Capabilities,Digital Marketing Capabilities and Firm Performance

\section{CONCLUSION}

In this literature review, the authors suggest that there are three possible relationships between dynamic capabilities, digital marketing capabilities and firm performance. The first relationship is that dynamic capabilities has a positive direct influence on firm performance. Second one is that dynamic capabilities will positively influence digital marketing capabilities. The last is that digital marketing capabilities will positively influence firm performance. This study is limited that the literature review is only based on one search engine which is Science Direct. Further study to discover empirical validation of the three relationships between dynamic capabilities, digital marketing capabilities and firm performance.

The authors suggest further study with evidence. It will contribute to theoretical and practical implication. The theoretical contribution will provide evidence of the relationship between dynamic capabilities, digital marketing capabilities and firm performance. The practical implication will give another horizon for owner or manager of SME that digital marketing can be used to improve firm performance.

\section{REFERENCES}

1. TAMBUNAN T. Entrepreneurship Development: Smes in Indonesia. J Dev Entrep [Internet]. 2007;12(01):95-118. Available from: http://www.worldscientific.com/doi/abs/10.1142/S1084946707000575

2. Hani U, Rachmania IN, Setyaningsih S, Putri RC. Patterns of Indonesian Women Entrepreneurship. Procedia Econ Financ [Internet]. 2012;4(Icsmed):274-85. Available from: http://linkinghub.elsevier.com/retrieve/pii/S2212567112003425

3. Market I. ANNUAL REPORT ON EUROPEAN SMEs Annual Report on European SMEs. 2017.

4. Mikro U. Perkembangan data usaha mikro, kecil, menengah

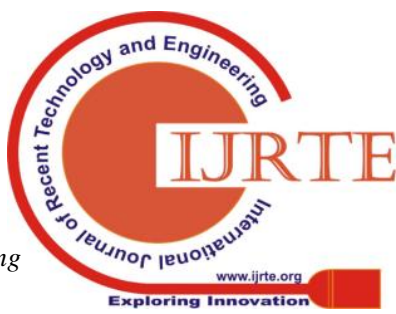




\section{Dynamic Capabilities and Digital Marketing in Small and Medium-Sized Enterprises (SMEs) in Indonesia: A}

Systematic Analysis of Literature and Conceptual Model

(umkm) dan usaha besar (ub) tahun 2016 - 2017. 2017;(1):2016-7.

5. Report A. Annual Report 2017 End Extreme Poverty • Boost Shared Prosperity. 2017;

6. Hamdani J, Wirawan C. Open Innovation Implementation to Sustain Indonesian SMEs. Procedia Econ Financ [Internet]. 2012;4(Icsmed):223-33. Available from: http://linkinghub.elsevier.com/retrieve/pii/S2212567112003371

7. Penetrasi \& perilaku pengguna internet indonesia. 2017;

8. Liberati A, Altman DG, Tetzlaff J, Mulrow C, Gøtzsche PC, John PA. The PRISMA statement for reporting systematic reviews and meta-analyses of studies that evaluate healthcare interventions: explanation and elaboration. BMJ. 2009;399:1-28.

9. Arifin Z. The effect of dynamic capability to technology adoption and its determinant factors for improving firm' $\mathrm{s}$ performance; toward a conceptual model. Procedia - Soc Behav Sci [Internet]. 2015;207:786-96. Available from: http://dx.doi.org/10.1016/j.sbspro.2015.10.168

10. Lin $\mathrm{Y}, \mathrm{Wu} \mathrm{L}$. Exploring the role of dynamic capabilities in fi rm performance under the resource-based view framework. J Bus Res [Internet]. 2014;67(3):407-13. Available from: http://dx.doi.org/10.1016/j.jbusres.2012.12.019

11. Wilden R, Gudergan SP, Nielsen BB. Dynamic Capabilities and Performance : Strategy, Structure and Environment. Long Range Plann [Internet]. 2013;46(1-2):72-96. Available from: http://dx.doi.org/10.1016/j.lrp.2012.12.001

12. Karimi J. The Role of Dynamic Capabilities in Responding to Digital Disruption: A Factor-Based Study of the Newspaper Industry. 2015;(January).

13. Ringov D. Dynamic capabilities and fi rm performance. Long Range Plann [Internet]. 2017;50(5):653-64. Available from: http://dx.doi.org/10.1016/j.lrp.2017.02.005

14. Jantunen A, Tarkiainen A, Chari S, Oghazi P. Dynamic capabilities , operational changes, and performance outcomes in the media industry. J Bus Res [Internet]. 2018;(June 2017):0-1. Available from: http://dx.doi.org/10.1016/j.jbusres.2018.01.037

15. Day GS, Schoemaker PJH. Adapting to Fast-Changing Markets and Technologies. 2016;58(4):59-77.

16. Wang ETG, $\mathrm{Hu} \mathrm{H}, \mathrm{Hu}$ PJ. Information \& Management Examining the role of information technology in cultivating firms ' dynamic marketing capabilities. Inf Manag [Internet]. 2013;50(6):336-43. Available from: http://dx.doi.org/10.1016/j.im.2013.04.007

17. Barrales-molina V, Martínez-lópez FJ, Gázquez-abad JC. Dynamic Marketing Capabilities : Toward an Integrative Framework. 2013;

18. Syuhada AA, Gambetta W. Online Marketplace for Indonesian Micro Small and Medium Enterprises Based on Social Media. 2013;11(Iceei):446-54.

19. Jiang X, Liu H, Fey C, Jiang F. Entrepreneurial orientation , network resource acquisition, and fi rm performance: A network approach. 2018;87(February):46-57.

20. Rezaei J, Ortt R, Rezaei J, Ortt R. functional performances Entrepreneurial orientation and fi rm performance : the mediating role of functional performances. 2018;

21. Sok P, Cass AO, Mony K. Achieving superior SME performance: Overarching role of marketing, innovation, and learning capabilities. Australas Mark J [Internet]. 2013;21(3):161-7. Available from: http://dx.doi.org/10.1016/j.ausmj.2013.04.001

22. Merrilees B, Rundle-thiele S, Lye A. Industrial Marketing Management Marketing capabilities: Antecedents and implications for B2B SME performance. Ind Mark Manag [Internet]. 2011;40(3):368-75. Available from: http://dx.doi.org/10.1016/j.indmarman.2010.08.005

23. Cacciolatti L, Hee S. Revisiting the relationship between marketing capabilities and fi rm performance: The moderating role of market orientation , marketing strategy and organisational power. J Bus Res [Internet]. 2016; Available from: http://dx.doi.org/10.1016/j.jbusres.2016.03.067

24. Day GS. Day_2011.2011;75(July):183-95.

25. Martin SL, Javalgi RG, Cavusgil E. Marketing capabilities, positional advantage, and performance of born global fi rms : Contingent effect of ambidextrous innovation. Int Bus Rev [Internet]. 2016; Available from: http://dx.doi.org/10.1016/j.ibusrev.2016.11.006

26. Martin SL, Javalgi RRG. Entrepreneurial orientation, marketing capabilities and performance: The Moderating role of Competitive Intensity on Latin American International New Ventures. J Bus Res [Internet]. 2016;69(6):2040-51. Available from: http://dx.doi.org/10.1016/j.jbusres.2015.10.149

27. Kim N, Shin S, Min S. Strategic marketing capability: Mobilizing technological resources for new product advantage $i$. J Bus Res [Internet]. 2016; Available from: http://dx.doi.org/10.1016/j.jbusres.2016.03.072
28. Bezawada R. The Effect of Customers' Social Media Participation on Customer Visit Frequency and Profitability : An Empirical Investigation. 2013;24(1):108-27.

\section{AUTHORS PROFILE}

My Name is Anton Wardaya, Doctoral Student at Doctor of Research Management program in Entrepreneurship and Innovation stream, at Bina Nusantara University, Indonesia. Lecturer in Entrepreneurship, Bina Nusantara University, my area of interest is Innovation.

Sasmoko, I am Professor in Bina Nusantara University, Indonesia

Head of Research interest in Educational Technology, Bina Nusantara University \& my area of interest is Educational Technology.

I am Idris Gautama So, Doctor of Philosophy (Ph.D) in marketing from Universiti Sains Malaysia. Former vice rector Global Employability and Entrepreneurship, former dean, school of business management in Bina Nusantara University. Lecturer in Entrepreneurship and Innovation Stream, at Bina Nusantara University.

Agustinus Bandur, Doctor of Philosophy (Ph.D) in Leadership and Management Education from The University of Newcastle, Australia. Senior Lecturer \& Strategic Research and Partnership Team Leader. My area of interest is Leadership and Management. 